\title{
CONSTRUCTION AND CHARACTERIZATION OF A BOVINE HERPESVIRUS 5 MUTANT WITH A DELETION OF THE GI, GE AND US9 GENES
}

\author{
Ana Cláudia Franco ${ }^{1 *}$; Sílvia de Oliveira Hübner²; Anna Paula de Oliveira³ ${ }^{3}$ Helena B. de C. Ruthner Batista ${ }^{1}$; \\ Paulo Michel Roehe ${ }^{1,3}$; Franciscus A.M. Rijsewijk ${ }^{1}$ \\ ${ }^{1}$ Departamento de Microbiologia, Instituto de Ciências Básicas da Saúde, Universidade Federal do Rio Grande do Sul, Porto \\ Alegre, RS, Brasil; ${ }^{2}$ Faculdade de Veterinária, Universidade Federal de Pelotas, Pelotas, RS, Brasil; ${ }^{3}$ Centro de Pesquisas \\ Veterinárias Desidério Finamor, Eldorado do Sul, RS, Brasil
}

Submitted: October 24, 2006; Returned to authors for corrections: May 31, 2007; Approved: November 19, 2007.

\begin{abstract}
Bovine herpesvirus 5 (BoHV-5) is a important cause of viral encephalitis in cattle in South America. Within the framework of developing a differential vaccine against BoHV-5, a deletion mutant was constructed based on a Brazilian BoHV-5 isolate. The target of the deletions were genes that code proteins implicated in the neurovirulence of BoHV-5, the glycoprotein I (gI), glycoprotein $\mathrm{E}(\mathrm{gE})$ and membrane protein US9. To construct the deletion mutant of BoHV-5, the flanking regions of all three genes were cloned in a prokaryotic plasmid. This deletion fragment was co-transfected with the viral DNA into bovine cells. Identification of deletion mutants was performed by immunostaining with an anti-gE monoclonal antibody. One of the gE negative viral populations found was purified, amplified and further examined by restriction endonuclesase analysis of its genomic DNA. The plaque sizes and penetration kinetics of the deletion mutant and wild type viruses were compared. The plaque sizes of the deletion mutant were significantly smaller than those of the parental strain ( $\mathrm{p} \leq 0.05)$, but no statistical differences were observed in penetration kinetics. The results indicate that the gI/ gE/US9 deletion mutant of BoHV-5 may have a reduced virulence in the host and is still viable enough to be a good candidate for the development of a BoHV-5 vaccine.
\end{abstract}

Key words: bovine herpesvirus 5, BoHV-5, deletion mutant, glycoprotein genes

\section{INTRODUCTION}

Bovine herpesvirus 5 (BoHV-5) is an Alphaherpesvirus which is responsible for a non suppurative meningoencephalitis in young bovines, occurring mostly in countries of South America, although it was first identified in Australia $(12,20)$. BoHV-5 shares many properties with other alphaherpesviruses of the genus Varicellovirus, to which also bovine herpesvirus 1 (BoHV-1), suid herpesvirus 1 (SuHV-1) and varicella zoster virus (VZV) belong. BoHV-5 has a double-stranded genome of about $138 \mathrm{~kb}$ and has at least 70 genes. Its genome has a Unique Long region of about $110 \mathrm{~kb}$ and a Unique Short region of about $10 \mathrm{~kb}$, which is bordered by inverted repeats of about 10 $\mathrm{kb}(9)$. The arrangement of the genes is essentially co-linear with the other alphaherpesviruses and it is expected that most of the functions of the encoded proteins are conserved. BoHV5 shows the highest homology with BoHV-1 (82\% on amino acid level), but BoHV-5 infections follow essentially a neurological course, different from the respiratory/reproductive symptoms caused by BoHV-1. It is presently unclear which differences between BoHV-5 and BoHV-1 are responsible for the enhanced neurovirulence of BoHV-5, although in a rabbit model several BoHV-5 genes have been found to contribute to its neurovirulence. Among these are the genes coding for glycoprotein I (gI), glycoprotein $\mathrm{E}(\mathrm{gE})$ and membrane protein US9 $(4,6)$. Glycoproteins gI and gE are type I transmembrane proteins, and functional regions have been identified on both their extracellular and cytoplasmic domains $(23,26,27)$. Like their

*Corresponding Author. Mailing address: Departamento de Microbiologia, Instituto de Ciências Básicas da Saúde, Universidade Federal do Rio Grande do Sul. Av. Sarmento Leite, 500, CEP 900150-170, Porto Alegre, RS, Brasil. Tel.: (51) 3316-3655 ou (51) 3316-4111. E-mail: ana.franco@ufrgs.br 
homologues encoded by other alphaherpesviruses, the glycoproteins gI and gE of BoHV-5 form a complex and are implicated in cell-to-cell spread mechanisms. Moreover, the gE gene of SuHV-1 is found to be essential for the anterograde transport of viral glycoproteins along axons (3) and this function may be shared by BoHV- $5 \mathrm{gE}$. The US9 protein is a type II transmembrane protein and has an extracellular domain of only a few amino acids and its cytoplasmic domain has a strongly conserved region. The role of the US9 protein of BoHV-5 has not been studied on the cellular level, but it probably also plays a role in the anterograde transport of viral glycoproteins along axons as has been found for the SuHV-1 US9 protein (10). Moreover, it may play a role in apoptosis of the host cell, as has been suggested for the US9 protein of BoHV-1 (19).

At present no vaccine is available for BoHV-5. Cross protection against BoHV-5 by a BoHV-1 vaccine has been found, for a less virulent BoHV-5 strain (2), but BoHV-1 vaccines probably can't protect against more virulent BoHV-5 strains (Spilki FR, unpublished results). A modified live vaccine of BoHV-5 should be sufficiently attenuated and be released from its neurovirulence to be safe. Therefore, it has been decided to construct a mutant of BoHV-5 from which the genes coding for glycoproteins $\mathrm{gI}$ and $\mathrm{gE}$ and for the US9 protein are deleted.

\section{MATERIALS AND METHODS}

\section{Virus strain and cells}

Madin-Darby bovine kidney cells (MDBK, ATCC-CCL 22) and Embryonic bovine tracheal cells (Ebtr) were grown in Minimal Essential Medium(MEM) supplemented with 5 to $10 \%$ of foetal bovine serum (FBS) and antibiotics. Cell cultures were grown at $37^{\circ} \mathrm{C}$ in a $5 \% \mathrm{CO}_{2}$ incubator. The EVI $88 / 95$ isolate was used as the BoHV-5 parental strain and it was isolated from a meningoencephalitis outbreak in the central region of Brazil in 1995.

\section{BoHV-5 viral DNA extraction and cloning}

Sub-confluent Ebtr cells grown in $900 \mathrm{~cm}^{2}$ roller bottles were infected with the EVI 88/95 strain of BoHV-5 virus at a multiplicity of infection of 0.1 to 1 . Approximately $36 \mathrm{~h}$ after infection, when typical herpesvirus cytopathic effect (CPE) was evident in about $90 \%$ of the cells, the supernatant was removed, clarified at 5000 $\mathrm{xg}$ for $20 \mathrm{~min}$ and ultracentrifuged at $100000 \mathrm{xg}$ for two $\mathrm{h}$ at $4^{\circ} \mathrm{C}$. The viral pellet was resuspended in TE pH 7.4 (10mM Tris, $1 \mathrm{mM}$ EDTA) and treated with sodium dodecyl sulfate (SDS) and proteinase $\mathrm{K}$ (final concentrations of $1 \%$ and $100 \mu \mathrm{g} / \mathrm{ml}$, respectively) for $1 \mathrm{~h}$ at $37^{\circ} \mathrm{C}$. The viral DNA was extracted with equilibrated phenol, precipitated with ethanol, resuspended in TE pH 7.4 and stored at $4^{\circ} \mathrm{C}$.

The genomic DNA of EVI 88/95 strain was digested with $B a m \mathrm{HI}$ and the obtained fragments were cloned randomly in pBR322, using standard methods (13). To construct the gI/gE/
US9 deletion fragment, the DNA fragments bordering the $\mathrm{gI} /$ gE/US9 locus were subcloned into the pCR Blunt plasmid (Invitrogen), using standard methods (24).

\section{Co-transfection of deletion fragment with wild type BoHV-5 DNA}

A BoHV-5 subclone, which contained the gI/gE/US9 deletion fragment, was linearized at the Hind III site, located in the plasmid, to allow the recombination process to take place. One $\mu \mathrm{g}$ of linearized plasmid and $2 \mu \mathrm{g}$ of BoHV-5 genomic DNA of EVI 88/95 strain were co-transfected into monolayers of Ebtr cells using the calcium phosphate method (13). The Ebtr cells were seeded on 6 well plates one day prior to the co-transfection at a concentration of $10^{6}$ cells per well. The tissue culture medium was refreshed $4 \mathrm{~h}$ before the transfection. One $\mathrm{ml}$ of precipitate was then used for each well containing the cells. Four $h$ after the co-transfection, the medium was replaced and the cells were treated for 1 min with $15 \%$ glycerol in $1 \mathrm{x}$ medium. After washing the cells two times with PBS, medium was added and the transfected cells were further incubated for $24 \mathrm{~h}$. One out of six wells was covered with semi-solid medium ( $1 \mathrm{x}$ medium with $1 \%$ agarose) to count the number of plaques 3 days after cotransfection. When at least seventeen plaques per well were obtained, the co-transfection was considered successful.

\section{Isolation and molecular characterization of the BoHV-5 gI/gE/ US9- deletion mutant}

Co-transfected cells of 5 wells and their medium were freeze/ thawed and collected in a $50 \mathrm{ml}$ tube. After clarification for 20 minutes at $500 \mathrm{x} \mathrm{g}$, the supernatant was used to infect new monolayers of Ebtr cells on 6-wells plates and semi-solid medium was overlaid. After the appearance of CPE, isolated viral plaques were picked and used to infect monolayers of Ebtr cells on a 96 wells plate. When CPE was visible, cells were fixated and an immunoperoxidase monolayer assay (IPMA) (16) was performed using a monoclonal antibody against $\mathrm{gE}$ (Mab 51) and an additional antibody against gC (MAb 14) (22). Viruses in wells, with clear CPE and without any staining with anti-gE Mab 51 were considered to be deletion mutant candidates. Supernatants of such wells were used to infect new cell monolayers and one candidate, named EVI 88/95 gI/gE/US9- was submitted to three more rounds of plaque purification under semi-solid medium.

To identify the borders of the deletion at the genomic level, the DNA of EVI 88/95 gI/gE/US9- virus was extracted and submitted to nucleotide sequence analysis. To characterize the gI bordering fragment the following primers were designed: P1: 5' cetcgcgatcgctttgctagtge 3' and P2: 5' gcgagcgcgeggacgcggc 3 '. These primers amplify a region between nucleotides 120721 and 122530 of the BoHV-5 genome (accession number AY261359). To analyze the US9 bordering fragment the following primers were used: P3: 5' cgccatcctggcgctagagc3' and P4: 5' gacgactacgaggtcgactacg 3 '. These primers amplify a region 
between nucleotides 126243 and 127760 . The amplified fragments were directly submitted to the nucleotide sequencing using a Beckman CEQ ${ }^{\mathrm{TM}} 8000$ eight-channel capillary DNA Analysis System (Beckman Coulter, Fullerton, CA).

\section{In vitro growth characteristics}

The plaque size assay was performed as described previously (11). Briefly, confluent MDBK monolayers prepared on 6-wells plates were infected with 50 p.f.u. of either the EVI 88/95 $\mathrm{gI} / \mathrm{gE} / \mathrm{US} 9^{-}$or the EVI 88/95 strain and grown under semisolid medium for five days. The monolayers were fixated, stained and the diameter of at least 50 viral plaques of each virus were measured.

Penetration kinetics was assessed by allowing approximately 500 p.f.u. of the EVI 88/95 gI/gE/US9- or the EVI 88/95 strain to adsorb on either MDBK or Ebtr monolayers for $1 \mathrm{~h}$ at $37^{\circ} \mathrm{C}$. At different time intervals $(5,3,20,30,45,60$ and $120 \mathrm{~min})$ p.i., the inoculum was removed and cells were overlaid with semi-solid medium and incubated for four days. In a control experiment, additional cell monolayers were infected with 500 p.f.u. of all viruses, without low $\mathrm{pH}$ buffer treatment. Monolayers were fixated, stained and viral plaques were counted at each time interval. The degree of penetration was calculated by comparison with the plaque count of the control experiment (set at 100\% penetration). All tests were done in triplicate.

One step growth curves were assessed following infection of preformed MDBK cell monolayers at a m.o.i. of 10 . Adsorption was allowed for 1 hour at $37^{\circ} \mathrm{C}$ before the inoculum was removed and extracellular virus inactivated with $1 \mathrm{M}$ sodium citrate $(\mathrm{pH} 3.0)$. The monolayers were then washed with fresh medium and incubated for different intervals $(3,5$, $7,9,11,13,16,24,36$ and 48 hours p.i.). After the incubation period, the supernatants were harvested and assayed for virus. All experiments were performed in triplicate. Virus titres were calculated according to the method of Spearmann and Kärber (25) and expressed as the $\log _{10}$ tissue culture infectious doses per $50 \mu \mathrm{l}\left(\mathrm{TCID}_{50} / 50 \mu \mathrm{l}\right)$.

\section{Statistical analysis}

The statistical analysis was carried out using ANOVA, comparing the mean results of plaque sizes and titres for each group. $\mathrm{P}$ values $\leq 0.05$ were considered to be statistically significant. The calculation was made using Data Supplemental Analysis for Excel (Microsoft Office XP, Microsoft, USA).

\section{RESULTS}

\section{Cloning of the US region of BoHV-5 strain EVI 88/95}

EVI 88/95 genomic DNA was digested with BamHI and the obtained fragments were cloned randomly in pBR322. The obtained clones were analysed by restriction enzyme digestioon. To identify the Bam $\mathrm{HI}$ fragment covering the Unique Short (US) region, all clones with inserts of about $14 \mathrm{~kb}$ to $17 \mathrm{~kb}$ were analysed further. Based on published BoHV-5 maps the BamHI fragment covering the US region is the Bam $\mathrm{HI} C$ fragment, but this could either be $16.35 \mathrm{~kb}$ (1) or $14.6 \mathrm{~kb}$ (9) depending on the BoHV-5 strain analysed. Based on the positions of the StuI sites bordering the US region (9) the $16.4 \mathrm{~kb}$ Bam HI fragment in the clone named pAC41 was identified as the EVI 88/95 fragment that covered the US region.

\section{Construction of a gI/gE/US9 deletion fragment}

To construct a recombination fragment that could be used to delete the $\mathrm{gI} / \mathrm{gE} / \mathrm{US} 9$ loci from the genome of BoHV-5 strain EVI 88/95, both an upstream and a downstream fragment had to be cloned (Fig. 1C). The upstream fragment that was chosen was the $1.8 \mathrm{~kb} \mathrm{NruI}$ fragment that starts $149 \mathrm{nt}$ upstream of the end of the $\mathrm{gG}$ coding region, covers the complete $\mathrm{gD}$ coding region and ends at the start of the $\mathrm{gI}$ coding region $(5,8)$. The downstream fragment that was chosen was $1.6 \mathrm{~kb}$ NotI fragment that starts at the end of the US9 coding region, covers the partial US1.67 gene and ends in the terminal repeat region (5). Both fragments were isolated from the pAC41 clone and subcloned into pCR-Blunt next to each other in the same orientation as found in the original 16.4 BamHI fragment. (Fig. 1B). The upstream fragment covering the complete gD coding region was only separated by a small part of the multiple cloning site of pCR-Blunt (about 30 nucleotides between the blunt site to the NotI site) from the downstream fragment covering the partial US1.67 gene and part of the terminal repeat region.

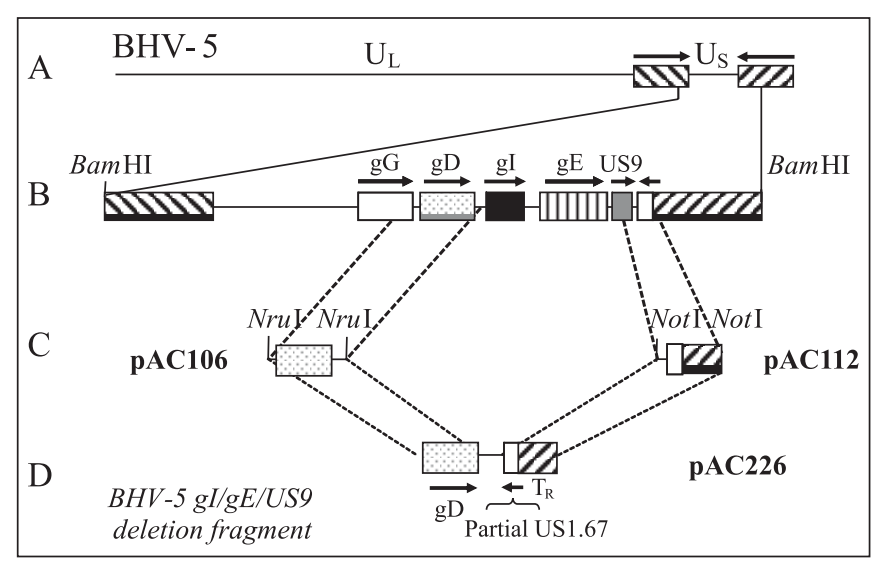

Figure 1. Diagram of the construction of the deletion fragment used to produce the BoHV-5 EVI 88/95 gI/gE/US9-. A indicates the structure of the BoHV-5 genome. The Unique Long (UL), the Unique Short (US) regions and the terminal and internal repeats (TR and IR) are indicated. The BamHI C fragment is indicated in $\mathrm{B}$. The $1.8 \mathrm{~kb} \mathrm{NruI}$ and $1.6 \mathrm{~kb}$ NotI fragments were cloned separately (C) and then together (D) to be used as a deletion fragment for the co-transfection. 


\section{Co-transfection, isolation and analysis of the BoHV-5 gI/gE/ US9- recombinant virus}

In order to generate a $\mathrm{gI} / \mathrm{gE} / \mathrm{US} 9$ deletion mutant of BoHV5, plasmid pAC226 was linearized with HindIII, 722 nucleotides upstream to the insert, site localized in the vector, and cotransfected with genomic DNA of wild type EVI 88/95. After co-transfection, about 100 primary plaques were found, a transfection efficiency considered sufficient to allow the formation of recombinants. After seeding the supernatant of the freeze/thawed primary plaque culture, 4 out of 290 plaques could be isolated that failed to react with anti-gE Mab 51. The viruses in the supernatants of these $4 \mathrm{gE}$ negative plaques were three times plaque purified and were tested again with anti-gE Mab 51. All four showed clear CPE and remained Mab51 negative (data not shown). One of these four $\mathrm{gE}$ negative viral populations was named BoHV-5 gI/gE/US9 ${ }^{-}$and multiplied on MDBK cells. The genomic DNA of the BoHV-5 gI/gE/US9was isolated and digested with BamHI to compare the restriction pattern with the DNA of the EVI 88/95 virus. As expected, the original $16.4 \mathrm{~kb}$ Bam HI fragment was absent in the pattern of the gI/gE/US9 mutant and a new BamHI fragment of $12.8 \mathrm{~kb}$ appeared (Fig. 2). This is consistent with a $3.6 \mathrm{~kb}$ deletion covering the $\mathrm{gI} / \mathrm{gE} / \mathrm{US} 9$ loci. No other gross rearrangements, other than the intended deletion were observed.

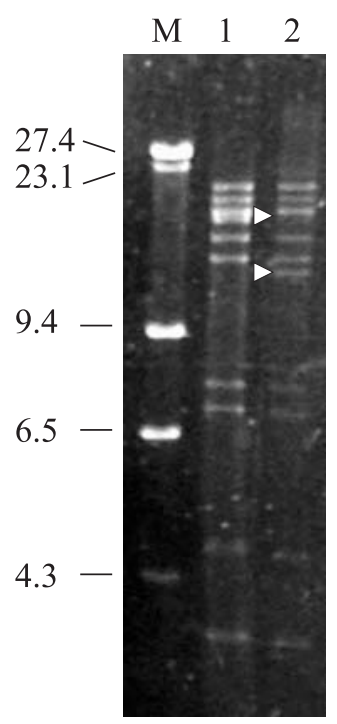

Figure 2. Restriction endonuclease analysis of viral DNA (EVI 88/95, first lane and EVI 88/95 gI/gE/US9-, second lane) digested with BamHI. The arrows indicate the loss of the 16.4 $\mathrm{kb}$ Bam HI fragment and the appearance of a new $12.8 \mathrm{~kb}$ Bam HI fragment in the deletion mutant. M indicates the DNA marker Lambda HindIII. The sizes of the bands are expressed in kilo base pairs $(\mathrm{kb})$.
The alignment of the nucleotide sequence obtained from the EVI88/95 $\mathrm{gI} / \mathrm{gE} / \mathrm{US}^{-}$showed that the right border of the $\mathrm{gI}$ upstream region has $98 \%$ homology with the end of the $\mathrm{gD}$ gene and stops just before the gI start codon (data not shown), indicating that the deletion started at the expected position. The sequence data of the US9 downstream region has $100 \%$ homology with the end of US9 gene and with part of the US1.67 gene (data not shown), indicating the deletion of almost all the US9 gene and the presence of part of the US1.67 gene, as expected, in the viral genome.

The immunoperoxidase assay performed with two monoclonal antibodies on cells infected with either the wild type or the EVI88/95 gI/gE/US9- revealed that both viruses expressed $\mathrm{gC}$, while only the wild type was positive for $\mathrm{gE}$ (Fig. 3).

\section{In vitro growth characteristics}

The mean plaque size of the EVI 88/95 gI/gE/US9- after 5 days post-infection was $0.19(+/-0.08 \mathrm{~mm})$, while the parental strain had a mean plaque size of $0.54(+/-0.06 \mathrm{~mm})$. The mean plaque size of EVI 88/95 gI/gE/US9- was only $35 \%$ of the size of the wild type virus, a difference that was considered statistically significant and indicates that the triple deletion mutant is impaired in its cell-to-cell spread.

The penetration kinetics of EVI 88/95 gI/gE/US9- on both MDBK cells and Ebtr cells were essentially the same as the parent strain (Fig. 4). Both the triple deletion mutant and the wild type strain could penetrate these cell types to a level of about $60 \%$ at $60 \mathrm{~min}$ post infection and reached a level of about $95 \%$ of penetration at $2 \mathrm{~h}$ post infection. The differences found between the mean penetration percentages were statistically not significant. These data suggest that the proteins encoded by the three genes (gI, gE and US9) do not play an important role in the penetration of the host cells tested.

The one step growth curves of EVI 88/95 and EVI 88/95 gI/ gE/US9- are shown in Fig. 5. The multiplication kinetics of both viruses were undistinguishable. In both cases, viral progeny was first detected at 7 hours p.i. and the maximum viral titres were reached at 36 hours p.i. when infectious titres were very similar (between $10^{6}$ and $10^{7} \mathrm{TCID}_{50}$ ).

\section{DISCUSSION}

The EVI 88/95 open reading frames of the genes encoding glycoproteins $\mathrm{gI}, \mathrm{gE}$ and membrane protein US9 could be identified by comparison with published nucleotide sequences amino acid sequences of the $\mathrm{gI}, \mathrm{gE}$ and US9 homologues of related alphaherpesviruses. This allowed us to design a deletion that encompasses all three reading frames and to introduce this deletion into the genome of BoHV-5 strain EVI $88 / 95$. However, a full analysis of the cis-regulatory sequences and a detailed transcription map of the region in which these 

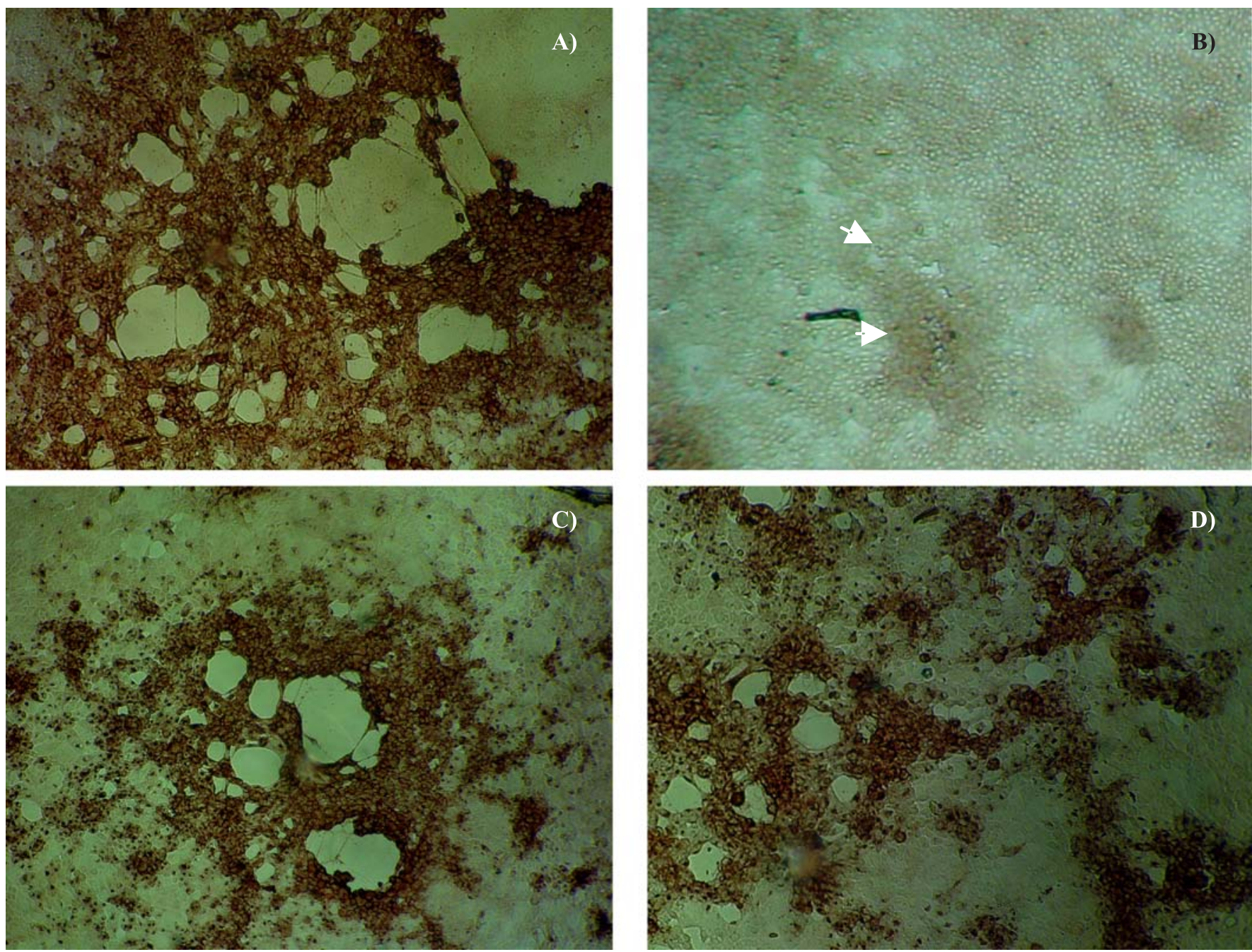

Figure 3. Immunoperoxidase monolayer assay on MDBK cells infected with EVI 88/95 (A and C) and EVI 88/95 gI/gE/US9- (B and $\mathrm{D})$ viruses using the anti-gE MAb 51 ( $\mathrm{A}$ and $\mathrm{B}$ ) and the anti-gC MAb 14 (C and D). Cells expressing $\mathrm{gE}$ and $\mathrm{gC}$ are stained in red. The arrows in B show unstained cells infected with the EVI 88/95 gI/gE/US9-.

genes are located are still missing. This is especially important with respect to the effects of the deletion on the neighboring genes: the glycoprotein $\mathrm{D}$ gene located upstream of the deletion and the BICP 4 gene located downstream. It is very likely that cis-regulatory sequences of one or both neighboring genes have been affected by the deletion. A similar case has been described for BoHV-1, where a polyadenylation signal is located between $\mathrm{gI}$ and $\mathrm{gE}$, which is used to process gI transcripts but which is also used for the processing of glycoprotein D transcripts (17). Given the high homology between the BoHV-5 and BoHV-1, this may also be the case for the transcripts of $\mathrm{gD}$ of BoHV-5. It is not clear where the polyadenylation signals for BICP4 transcripts are located, but they may as well be located within the deleted region. Both the $\mathrm{gD}$ and the $\mathrm{BICP} 4$ genes are essential for viral replication and therefore it is unlikely that their expression is seriously affected. Nevertheless, the deletion of $\mathrm{gI}, \mathrm{gE}$ and US9 may have modified their levels of expression and consequently the viability of the deletion mutant. In case of a double deletion of gI and $\mathrm{gE}$ of BoHV-1, significantly lower titres were found in vivo compared to the parental strain (14). The BoHV-5 deletion mutant that was selected was studied using restriction enzyme analysis and partial sequencing of the borders of the deletion and no obvious changes in its genome other than the intended deletion of the gI, gE and US9 encoding region could be observed. However, this analysis couldn't exclude unintended additional changes, like small insertions or deletions or nucleotide substitutions. 


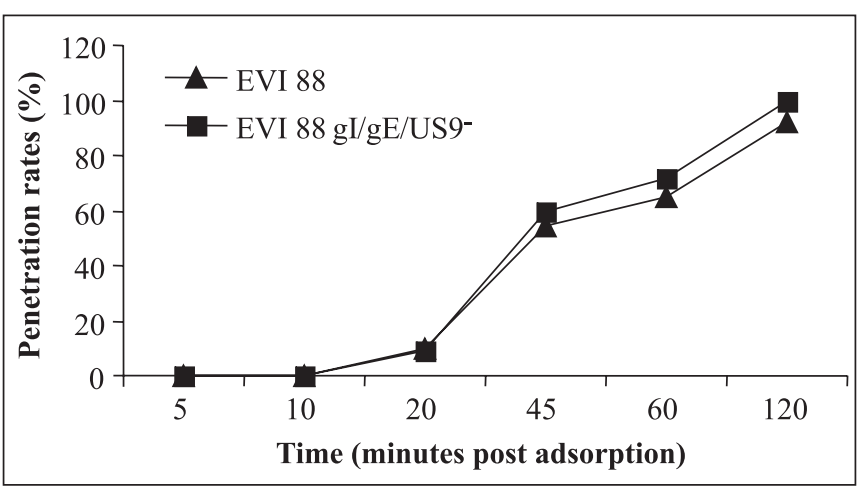

Figure 4. Comparison of the penetration kinetics of wild type strain EVI 88/95 and deletion mutant EVI 88/95 gI/gE/US9- in MDBK cells.

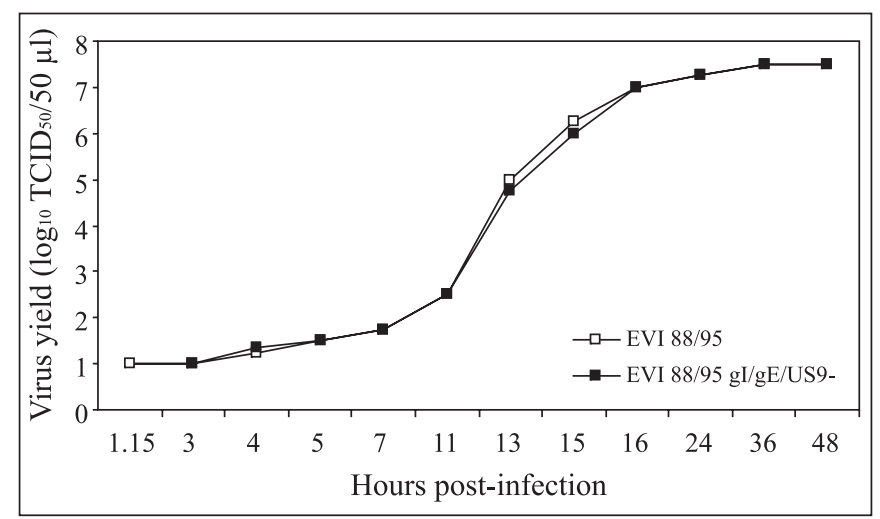

Figure 5. Growth kinetics of EVI 88/95 ( $\square$ ) and EVI 88/95 gI/gE/ US9- (ם) in MDBK cells. Virus titres in TCID50/50 ml, are expressed as the reciprocal of virus titres in $\log 10$.

For an attenuated live vaccine, safety as well as efficacy are important. Consequently, the triple deletion mutant should have lost its virulence, but could still be viable enough to be able to induce immunity to protect against a challenge with a wild type BoHV-5 strain. The in vitro properties of the triple deletion mutant indicate that it is attenuated: the small plaque phenotype of the triple deletion mutant suggests that the mutant is attenuated in vivo. The glycoproteins gI and gE of BoHV-5 as well as the homologous $\mathrm{gI}$ and $\mathrm{gE}$ proteins of related alphaherpesviruses are implicated in cell-to-cell spread mechanisms $(6,21)$. Consequently, the small plaque phenotype in monolayers of bovine cells under semi-solid medium growth conditions was expected. $\mathrm{gI}$ or $\mathrm{gE}$ deletion mutants, or $\mathrm{gI} / \mathrm{gE}$ double deletion mutants of related alphaherpesviruses all have a small plaque phenotype and the mutants tested in vivo showed an attenuated phenotype. Whether the US9 deletion contributed to the small plaque phenotype is not clear. A BoHV-1 US9 deletion mutant does not have a small plaque phenotype (11) and the role of the US9 protein may be more clear in neuronal cell-to-cell spread along axons (10). In case of BoHV-1, deletion of the gE gene alone already attenuated the virus sufficiently to be safe in young calves (7). The multiplication and penetration kinetics of the triple deletion mutant are unaffected when compared to the wild type. These results indicate that none of the deleted genes are important either for the virus penetration or replication in MDBK cells, which was already shown for gI, gE and US9 homologues in other alphaherpesviruses $(4,11)$ and suggest that the deletion mutant is viable enough to be used as a candidate for a viral vaccine.

Whether the BoHV-5 triple deletion is sufficiently safe and efficacious as a vaccine has still to be confirmed in vivo. In case this virus is still too virulent, additional mutations that lower its virulence, without affecting immunity triggering, or with enhancing its immunization properties have to be introduced. One option is the additional deletion of the virus-host shut off gene (vhs) that is known to down regulate the expression of MHC class I molecules (15).

The deletion of the $\mathrm{gI}$ and $\mathrm{gE}$ genes has the additional advantage that the triple deletion mutant can be used as a marker vaccine. Marker vaccines allow the serological differentiation between vaccinated and infected animals and are a useful tool in a control program. For BoHV-1 and SuHV-1 successful control programs are in progress based on the use of $\mathrm{gE}$, or $\mathrm{gI} / \mathrm{gE}$ deletion mutants $(28,18)$. In case of BoHV-5, serological studies are complicated by cross reaction with BoHV-1 positive sera. This may be solved by the use of tests that are specific for antibodies against the BoHV-5 $\mathrm{gI} / \mathrm{gE}$ complex or by the simultaneous control of BoHV-1.

In conclusion, a BoHV-5 gI/gE/US9- triple deletion mutant was constructed that may be used in vaccines to control BoHV5 infections and reduce the incidence of viral induced encephalitis in cattle.

\section{RESUMO}

Construção e caracterização de um mutante herpesvírus bovino 5 com uma deleção nos genes gI, gE e US9

O herpesvírus bovino 5 (BoHV-5) é uma causa importante de encefalite viral em bovinos na América do Sul. Buscando o desenvolvimento de uma vacina diferencial contra o BoHV-5, um mutante deletado foi construído com base em um isolado brasileiro deste vírus. $\mathrm{O}$ alvo das deleções foram genes que codificam proteínas implicadas na neurovirulência do BoHV-5, a glicoproteína I (gI), a glicoproteína E (gE) e a proteína de membrana US9. Para construir o mutante deletado de BoHV-5, as regiões flanqueadoras dos três genes foram clonadas em um plasmídeo procarioto. Este fragmento de deleção foi co- 
transfectado com o DNA viral em células de bovinos. A identificação dos mutantes deletados foi feita por meio da técnica de imunoperoxidase com um anticorpo monoclonal anti-gE. Uma das populacões virais $\mathrm{gE}$ negativas encontradas foi purificada, amplificada e seu genoma foi examinado por análise de restrição enzimática. Os tamanhos de placas virais e taxas de penetração do vírus mutante foram determinados e comparados com os do vírus selvagem. As placas virais do vírus mutante deletado foram significativamente menores do que as do vírus selvagem ( $\mathrm{p} \leq$ $0,05)$, mas não foram encontradas diferenças significativas quando comparadas as taxas de penetração dos dois vírus. Estes resultados indicam que o vírus mutante deletado $\mathrm{gI} / \mathrm{gE} /$ US9 de BoHV-5 pode apresentar virulência reduzida e é viável o suficiente para ser um bom candidato para o desenvolvimento de uma vacina contra o BoHV-5.

Palavras chave: herpesvírus bovino 5, BoHV-5, mutantes deletados, genes de glicoproteínas

\section{REFERENCES}

1. Bulach, D.M.; Studdert, M.J. (1990). Comparative genome mapping of bovine encephalitis herpesvirus, bovine herpesvirus 1, and buffalo herpesvirus. Arch. Virol., 113, 17-34.

2. Cascio, K.E.; Belknap, E.B.; Schultheiss, P.C.; Ames, A.D.; Collins, J.K. (1999). Encephalitis induced by bovine herpesvirus 5 and protection by prior vaccination or infection with bovine herpesvirus 1. J. Vet. Diagn. Invest., 134-139.

3. Chang, T.H.; Enquist, L.W. (2003). The role of glycoprotein E in directional spread of pseudorabies virus in neuronal circuits. $28^{\text {th }}$ International Herpesvirus Workshop, Madison, USA, p.104.

4. Chowdhury, S.I.; Lee, B.J.; Ozkul, A.; Weiss, M.L. (2000). Bovine herpesvirus 5 glycoprotein $\mathrm{E}$ is important for neuroinvasiveness and neurovirulence in the olfactory pathway of the rabbit. J. Virol., 74, 2094-2106.

5. Chowdhury, S.I.; Onderci, M.; Bhattacharjee, P.S.; Al-Mubarak, A.; Weiss, M.J.; Zhou, Y. (2002). Bovine herpesvirus 5 (BHV-5) Us9 is essential for BHV-5 neuropathogenesis. J. Virol., 76, 3839-3851.

6. Dingwell, K.S.; Johnson, D.C. (1998). The herpes simplex virus gEgI complex facilitates cell-to-cell spread and binds to components of cell junctions. J. Virol., 72, 8933-8942.

7. Engelenburg van, F.A.C.; Kaashoek, M.J.; Rijsewijk, F.A.M.; Burg van der, L.; Moerman, A.; Gielkens, A.L.J.; Oirschot van, J.T. (1994). A glycoprotein E deletion mutant of bovine herpesvirus 1 is avirulent in calves. J. Gen. Virol., 75, 2311-2318.

8. Engelhardt, T.; Keil, G.M. (1996). Identification and characterization of the bovine herpesvirus 5 US4 gene and gene products. Virology, 225, 126-135.

9. Engels, M.; Giuliani, C.; Wild, P.; Beck, T.M.; Loepfe, E.; Wyler, R. (1986). The genome of bovine herpesvirus 1 (BHV-1) exhibiting a neuropathogenic potential compared to known BHV-1 strains by restriction site mapping and cross-hybridization. Virus Res., 6, 5773.

10. Enquist, L.W.; Tomishima, M.J.; Gross, S.; Smith, G.A. (2002). Directional spread of an á-herpesvirus in the nervous system. Vet. Microbiol., 86, 5-16.

11. Franco, A.C. (2001) Recombinantes de herpesvirus bovino tipo 1 com deleções nos genes gE e US9, Porto Alegre, Brasil, 139 p. (Doctoral thesis, Universidade Federal do Rio Grande do Sul).
12. French, E.L. (1962). A specific virus encephalitis in calves: isolation and characterization of the casual agent. Aust. Veter. J., 38, 555556.

13. Graham, F.L.; van der Eb, A.J. (1973). A new technique for the assay of infectivity of human adenovirus 5 DNA. Virology, 52, 456-467.

14. Kaashoek, M.J.; Rijsewijk, F.A.; Ruuls, R.C.; Keil, G.M.; Thiry, E.; Pastoret, P.P.; Van Oirschot, J.T. (1998). Virulence, immunogenicity and reactivation of bovine herpesvirus 1 mutants with a deletion in the $\mathrm{gC}, \mathrm{gG}, \mathrm{gI}, \mathrm{gE}$, or in both the $\mathrm{gI}$ and $\mathrm{gE}$ gene. Vaccine, 16, 802809 .

15. Koppers-Lalic, D.; Rijsewijk, F.A.; Verschuren, S.B.; van Gaans-Van den Brink, Neisig, A.; Ressing, M.E.; Neefjes, J.; Wiertz, E.J. (2001). The UL41-encoded virion host shutoff (vhs) protein and vhsindependent mechanisms are responsible for down-regulation of MHC class I molecules by bovine herpesvirus 1. J. Gen. Virol., 82, 207181.

16. Kramps, J.A.; Magdalena, J.; Quak, J.; Weerdmeester, K.; Kaashoek, M.J.; Maris-Veldhuis, M.A.; Rijsewijk, F.A.; Keil, G.; Van Oirschot, J.T. (1994). A simple, specific, and highly sensitive blocking enzymelinked immunosorbent assay for detection of antibodies to bovine herpesvirus 1. J. Clin. Microbiol., 32, 2175-2181.

17. Leung-Tack, P.; Audonnet, J-C.; Riviere, M. (1994). The complete DNA sequence and the genetic organization of the short unique region (Us) of the bovine herpesvirus type 1 (ST strain). Virology, 199, 409-421.

18. Muller, T.; Batza, H.J.; Schluter, H.; Conraths, F.J.; Mettenleiter, T.C. (2003). Eradication of Aujesky's disease in Germany. J. Vet. Med. B., 50, 207-13.

19. Nakamichi, K.; Mastsumoto, Y.; Otsuka, H. (2002). Bovine herpesvirus 1 US ORF8 protein induces apoptosis in infected cells and facilitates virus egress. Virology, 304, 24-32.

20. Perez, S.E.; Vagnozzi, A.; Sur, J.H.; Odriozola, E.; Campero, C.M.; Odeon, A.C. (2003). Retrospective analysis of cases with a diagnosis of cerebrocortical necrosis and its relation with type 5 bovine herpesvirus. Rev. Arg. Microbiol., 35, 69-73.

21. Rebordosa, X.; Pinol, J.; Perez-Pons, J.A.; Lloberas, J.; Naval, J.; Serra-Hartmann, X.; Espuna, E.; Querol, E. (1996). Glycoprotein E of bovine herpesvirus type 1 is involved in virus transmission by direct cell-to-cell spread. Virus Res., 45, 59-68.

22. Rijsewijk, F.A.; Kaashoek, M.J.; Langeveld, J.P.; Maris-Veldhuis, M.A.; Magdalena, J.; Verschuren, S.B.; Meloen, R.H.; Van Oirschot, J.T. (2000). Epitopes on glycoprotein E and on the glycoprotein E/ glycoprotein I complex of bovine herpesvirus 1 are expressed by all of 222 isolates and vaccine strains. Arch. Virol., 145, 921-936.

23. Rychlowski, M.; Rijsewijk, F.A.M.; Bienkowska-Szewczyk, K. (2001). Tyrosine 467 in cytoplasmic tail of glycoprotein E of bovine herpesvirus 1 is essential for $\mathrm{gE} / \mathrm{gI}$ intracellular trafficking. $26^{\text {th }}$ International Herpesvirus Workshop, Regensburg, Alemanha, p.322.

24. Sambrook, J.; Russel, D.W. Molecular Cloning: a Laboratory Manual. $3^{\text {rd }}$ ed. Cold Spring Harbor Laboratory Press, New York, USA, 2001

25. Mahy, W.J., Kangro, H.O. (1996). Quantitation of virus. In: Mahy, W.J.; Kangro, H.O. Virology Methods Manual. Academic Press, London, England, p.35-44.

26. Tirabassi, R.S.; Townley, R.A.; Eldridge, M.G.; Enquist, L.W. (1997). Characterization of pseudorabies virus mutants expressing carboxyterminal truncations of $\mathrm{gE}$ : evidence for envelope incorporation, virulence, and neurotropism domains. J. Virol., 71, 6455-6464.

27. Tyborowska, J.; Bienkowska-Szewczyk, K.; Rychlowski, M.; Van Oirschot, J.T.; Rijsewijk, F.A. (2000). The extracellular part of glycoprotein $\mathrm{E}$ of bovine herpesvirus 1 is sufficient for complex formation with glycoprotein I but not for cell-to-cell spread. Arch. Virol., 145, 333-351.

28. Van Oirschot, J.T. (1999). Diva vaccines that reduce virus transmission. J. Biotechnol., 73, 195-205. 